\title{
Analisis Meredam Angka Kemiskinan Melalui Pendekatan Ekonomi Hijau di Desa Pahlawan Kecamatan Tanjung Tiram Kabupaten Batu Bara
}

\author{
Annisa Ilmi Faried ${ }^{1^{*}}$ \\ ${ }^{1}$ Fakultas Sosial Sains Program Studi Ekonomi Pembangunan Universitas Pembangunan Panca Budi \\ Jl. Gatot Subroto No.km, Simpang Tj., Kec. Medan Sunggal, Kota Medan, Sumatera Utara 20122 \\ *e-mail : annisailmi@dosen.pancabudi.ac.id
}

Artikel Info
Received :
23 Agustus 2019
Revised :
09 Desember 2019
Accepted :
11 Juni 2020

Copyright@ 02020 , Ekonomikawan : Jurnal IImu ekonomi dan Studi Pembangunan. This is an open access article under the
Desa Pahlawan terus mengalami peningkatan jumlah penduduk setiap tahunnya yang mengakibatkan desa tersebut mengalami perubahan yang dipengaruhi oleh keberlangsungan pembangunan pada aspek lingkungan. Penelitian ini adalah lanjutan dari penelitian saya yang berjudul Analisis Dampak Pencemaran Lingkungan Terhadap Faktor Sosial Ekonomi Pada Wilayah Pesisir. Yang perlu dilakukan saat ini adalah mempertemukan antara ekonomi dan lingkungan dengan cara mewujudkan progres peningkatan ekonomi terbarukan yang berasal dari alam tanpa merusaknya, artinya bahwa kelestarian lingkungan akan menjamin keberlanjutan pembangunan untuk generasi yang akan datang. Variabel yang peneliti gunakan adalah Ekonomi Hijau dengan variabel pendidikan $\left(\mathrm{X}_{1}\right)$, akses nelayan $\left(\mathrm{X}_{2}\right)$, kesehatan $\left(\mathrm{X}_{3}\right)$, pengelolaan lingkungan $\left(\mathrm{X}_{4}\right)$, pendapatan $\left(\mathrm{X}_{5}\right)$ dan meredam angka kemiskinan (Y). Dari hasil penelitian bahwa pendidikan, kesehatan, pendapatan berpengaruh signifikan terhadap ekonomi hijau. Untuk variabel akses nelayan dan pengelolaan lingkungan tidak berpengaruh signifikan terhadap meredam angka kemiskinan. Sedangkan pada variabel pendidikan, kesehatan, pengelolaan lingkungan, pendapatan berpengaruh signifikan terhadap meredam angka kemiskinan.

Kata kunci: Ekonomi Hijau, Pendidikan, Akses Nelayan, Kesehatan, Pengelolaan Lingkungan, Pendapatan, dan Kemiskinan. 


\section{Analysis of Reducing Poverty Through the Green Economic Approach Pahlawan Village, Tanjung Tiram District Batu Bara Regency}

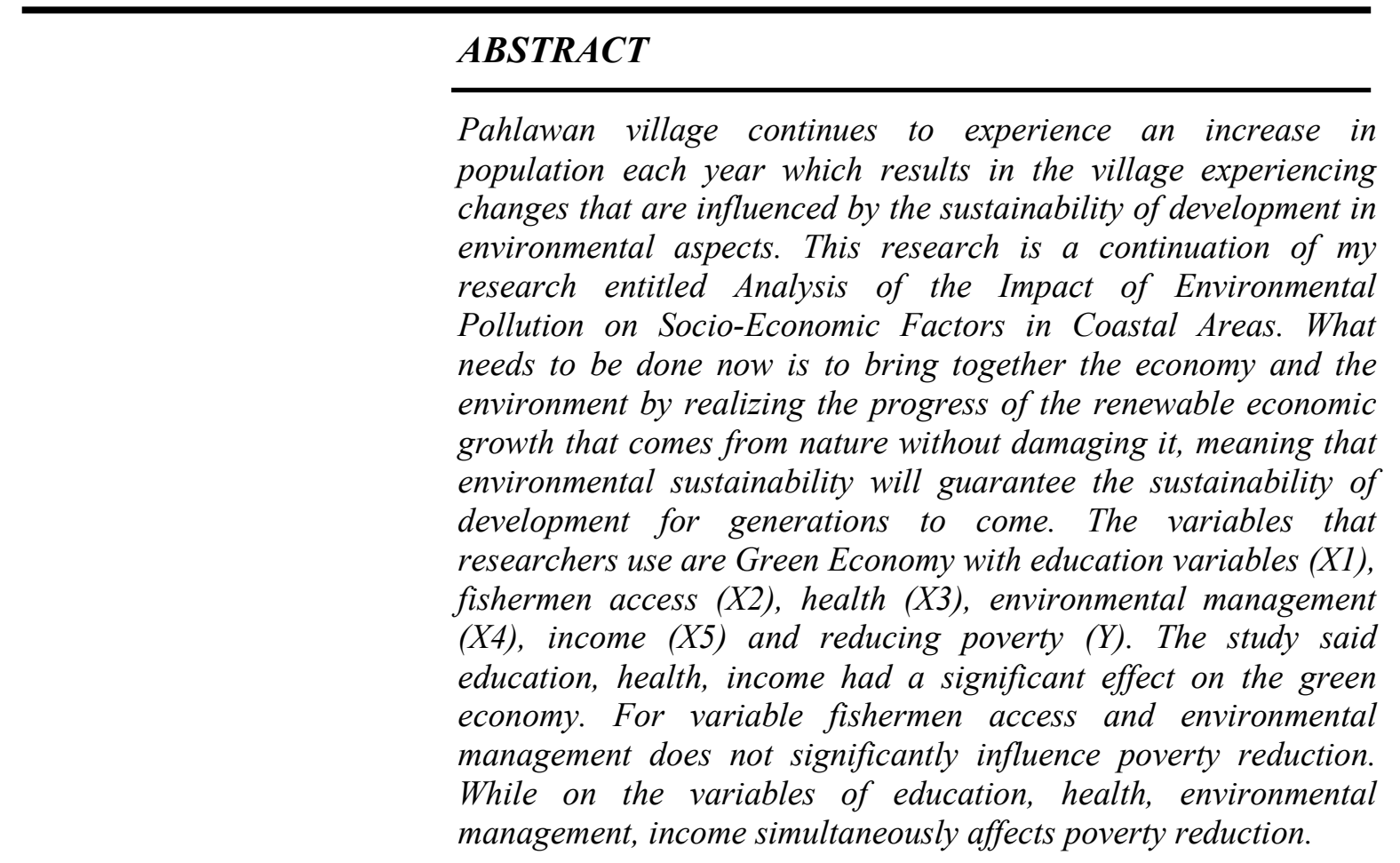

Keywords: Education, Fishermen access, Health, Environmental management, and Income.

\section{PENDAHULUAN}

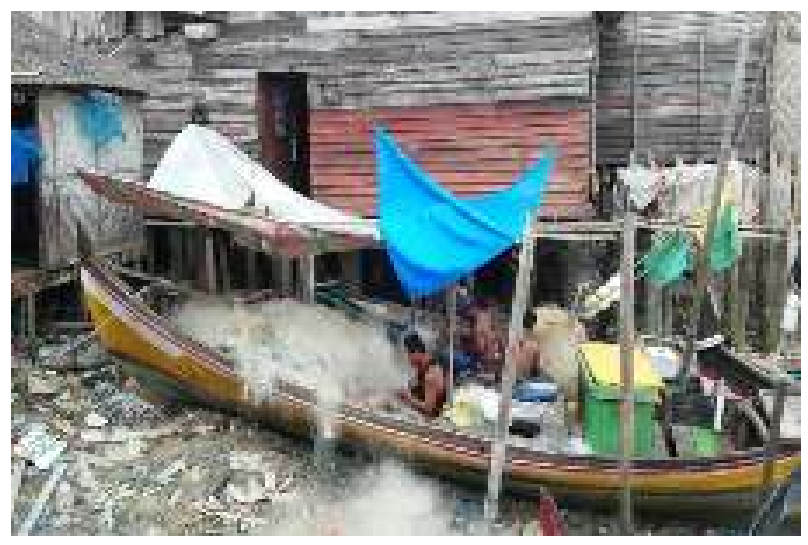

Gambar 1. Kondisi Nelayan, Tahun 2019

Gambar 1 menunjukkan bahwa di Desa Pahlawan menghadapi 2 (dua) permasalahan yang sampai dengan hari ini belum mampu teratasi yaitu masalah kesejahteraan serta konservasi wilayah pesisir dan membudidayakan hasil tangkap sebagai bagian dari kehidupan mereka. Kebijakan ekonomi jika dikaitkan dengan ekonomi lingkungan 
seharusnya bisa mendorong baik itu pemerintah maupun masyarakat tidak hanya terfokus pada pelestarian lingkungannya saja tetapi lebih dominan menuju mensejahterakan masyarakat sesuai pada sila ke 5 (lima) yang menjadi permasalahan utama dalam ekonomi hijau.

Ekonomi hijau saat ini menjadi fokus, karena masalah-masalah lingkungan disebabkan oleh kondisi masyarakat yang miskin, lemahnya peran serta masyarakat dan komitmen institusi untuk mewujudkan pembangunan berkelanjutan itu sendiri. Yang harus kita sadari bersama adalah hal yang utama dalam ekonomi hijau adalah kesejahteraan sosial sedangkan untuk kesejahteraan ekonomi hanyalah tambahan dari kesejahteraan sosial. Penelitian Annisa Ilmi Faried (2018) mengatakan bahwa untuk menanggulangi pencemaran lingkungan terhadap faktor sosial ekonomi semestinya posisi sosial mereka tetap marginal dalam proses transaksi ekonomi yang timpang dan eksploitatif sehingga sebagai pihak produsen, nelayan tidak memperoleh bagian pendapatan yang besar. Kelompok diuntungkan disini yakni tauke atau penyalur. Latar belakang pendidikan rendah, akses terhadap air bersih yang terbatas, kualitas lingkungan yang kotor, kebiasaan membuang sisa makanan rumah tangga di pekarangan rumah sehingga menyebabkan timbunan limbah yang semakin hari semakin banyak, akses kesehatan yang minim, pendapatan yang tidak menentu merupakan gambaran yang terjadi di di kawasan tersebut.

Pentingnya riset ini ditujukan untuk dapat menganalisis tentang meredam angka kemiskinan melalui pendekatan ekonomi hijau meliputi pendidikan (biaya, dorongan orangtua, sarana dan prasarana), akses nelayan (sarana transportasi, jarak tempuh, hasil penjualan), kesehatan (gizi, jaminan kesehatan, pelayanan kesehatan), pengelola lingkungan (kesadaran masyarakat, hidup sehat, kebersihan), pendapatan (modal, lama melaut, pengalaman kerja). Untuk meredam angka kemiskinan meliputi meningkatkan kualitas sumber daya manusia, ikatan kerja nelayan, peranan kelembagaan. Ekonomi hijau yang dibahas adalah akses layanan sampah, pengelolaan limbah, serta kualitas dan ketersediaan air bersih.

\section{KAJIAN TEORI}

Hal yang terpenting dari rencana pembangunan, apabila dilihat dari konsep ekonomi hijau melalui pendekatan yang komprehensif antara ketergantungan ekonomi dan ekosistem dengan melihat bagaimana mengatur jumlah alam yang sedikit dari aktivitas ekonomi secara berkesinambungan yang ditetapkan dalam prioritas nasional dalam jangka panjang untuk tahun 2005-2025 (UU No 17/2007), bahwa kebijakan yang diatur sebagai implementasi green economic membangun peningkatan ekonomi yang sejalan dengan kaidah pemeliharaan lingkungan serta menemukan sumber baru melalui penggunaan SDA sekitar sehingga menciptakan lapangan pekerjaan untuk menurunkan angka kemiskinan secara kontiniu. Dikaitkannya Ekonomi hijau dengan pengentasan kemiskinan adalah untuk mensejahterakan kehidupan masyarakat sekitar.

Peneliti berusaha mengaitkan cara mengatasi kemiskinan dengan pendekatan ekonomi hijau, dengan melihat bagaimana pengaruh keterkaitan ekonomi hijau dalam meredam angka kemiskinan di Desa Pahlawan Kecamatan Tanjung Tiram Kabupaten Batu Bara. Pentingnya pengelolaan dalam pendekatan ekonomi hijau untuk meredam angka kemiskinan agar terjaganya lingkungan yang baik dan tetap lestari maka diperlukan kesadaran masyarakat dan terjaganya kebersihan laut dalam meningkatkan kualitas SD yang baik juga untuk meningkatkan produktifitas masyarakat dalam mengelola sumber daya yang ada di lingkungan mereka. Kenyataan ini terjadi di Desa Pahlawan adalah karena kurangnya pengetahuan, pendidikan dan juga kesadaran mengakibatkan lingkungan 


\section{EKONOMIKAWAN : Jurnal Ilmu Ekonomi dan Studi Pembangunan}

I55N : $1693-7600$ (print), 155N : 2598-0157 (Online), hutp://fumal_umstiacid//index.php/ekawan

yang kotor hanya dibiarkan begitu saja sehingga lama kelamaan menjadi sebuah lingkungan kumuh yang berada di lingkungan pemukiman padat penduduk, otomatis jika dibiarkan secara terus menerus maka lingkungan akan tercemar menyebabkan kualitas laut berkurang sehingga mengakibatkan banyaknya sumber daya ikan mati, dan jika itu yang terjadi terpaksa mereka harus mencari wilayah baru untuk melanjutkan profesi mereka masing-masing untuk menutupi kebutuhan pokok sehari-hari.

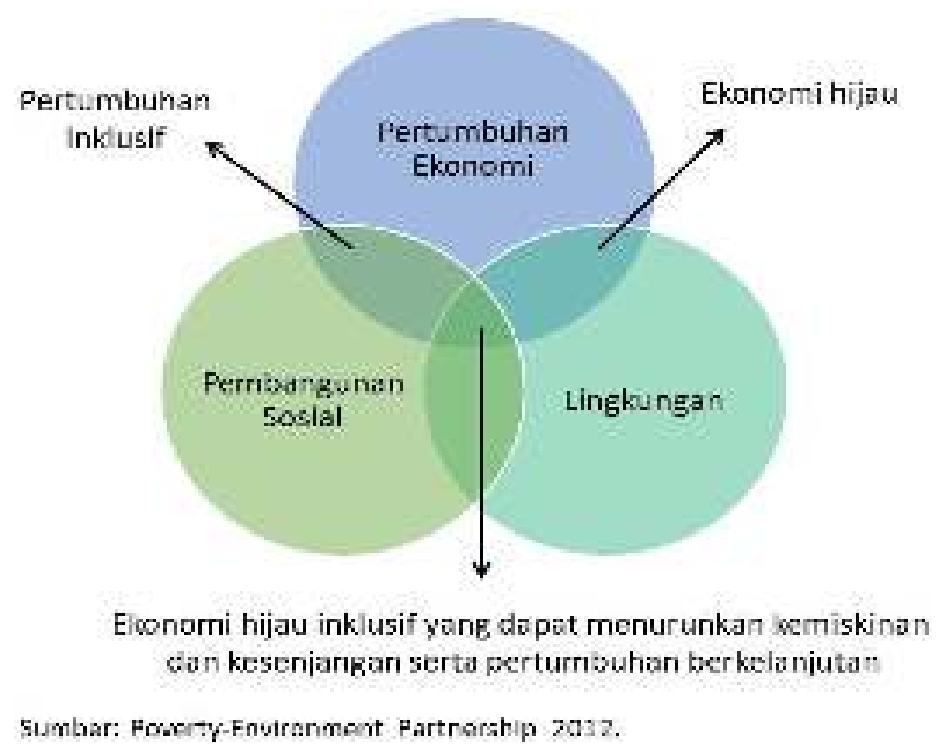

Gambar 2. Pola Pembangunan Berkelanjutan

Dari gambar 2 di atas bahwa pembangunan berkelanjutan menyatu dengan pertumbuhan ekonomi, pembangunan sosial dan lingkungan yang menunjukkan bagaimana saling berintegrasi dari nilai-nilai ekonomi, nilai sosial dan nilai lingkungan untuk meningkatkan kesejahteraan masyarakat pada program SDGs (Sustainable Development Goals) untuk diwujudkan dalam bentuk tindakan atau kegiatan nyata.

\section{METODE}

Metode yang digunakan adalah metode kuantitatif yang di dukung dengan SEM. Data di dibagikan melalai kuesioner kepada para penduduk. Analisis SEM mempunyai tujuh tahapan, yaitu, (1) pengembangan model teoritis, (2) pengembangan diagram jalur, (3) konversi diagram jalur ke persamaan struktural, (4) memilih matriks input dan jenis estimasi, (5) mengidentifikasi model, (6) menilai kriteria goodness of fit, (7) menginterprestasikan hasil. Adapun konsep kerangka konsep dapat dilihat pada gambar berikut : 


\section{EKONOMIKAWAN : Jurnal IImu Ekonomi dan Studi Pembangunan}

I55N : 1693 -7600 (print), 155N : 2598 -0157 (Online), http://fumd.umstiac.id/index.php/ekawan

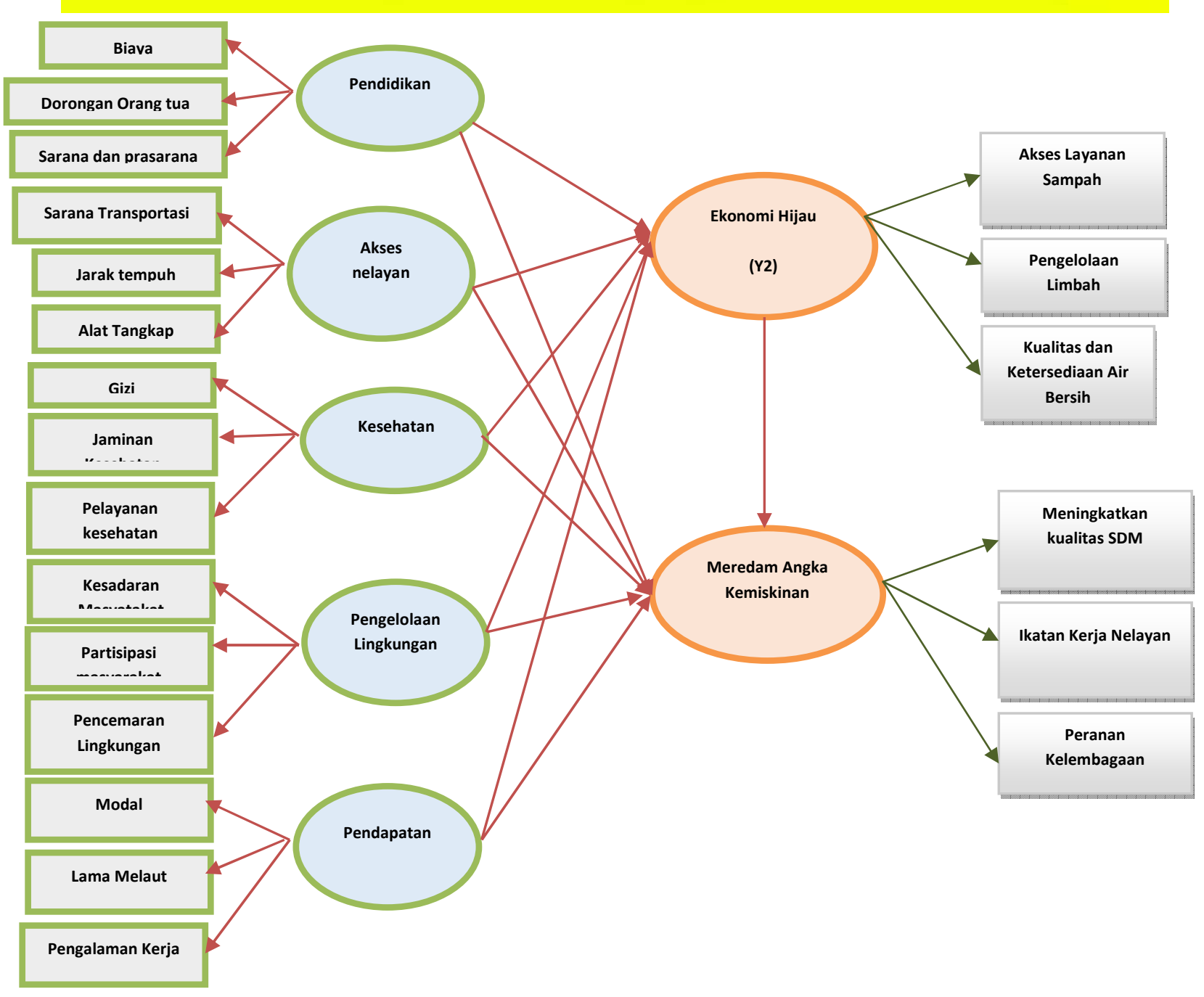

Gambar 3. Kerangka Konsep Penelitian 


\section{HASIL DAN PEMBAHASAN}

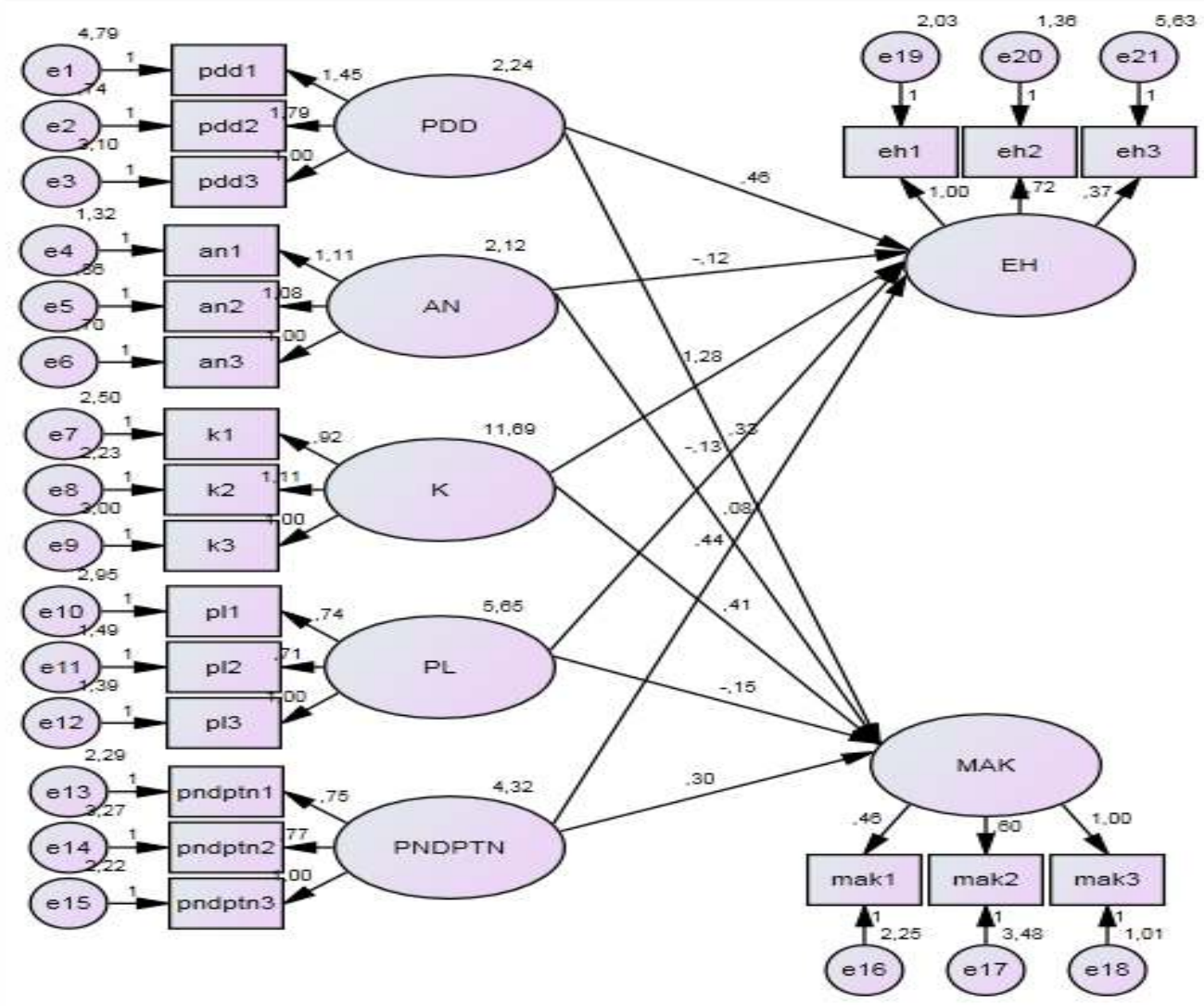

Gambar 4. Kerangka Output Amos

Tabel 1. Hasil Pengujian Kelayakan Model Penelitian Untuk Analisis SEM

\begin{tabular}{|c|c|c|c|}
\hline Goodness of Fit Indeks & Cut of Value & Hasil Analisis & Evaluasi Model \\
\hline $\begin{array}{l}\text { Min fit function of } \\
\text { chi-square }\end{array}$ & $\mathrm{p}>0,05$ & $(\mathrm{P}=0.080)$ & Fit \\
\hline Chisquare & $\begin{array}{c}\text { Carmines \& Melver } \\
(1981) \\
\text { Df }=168=129.69\end{array}$ & 1299,206 & Fit \\
\hline $\begin{array}{c}\text { Non Centrality Parameter } \\
\text { (NCP) }\end{array}$ & $\begin{array}{c}\text { Penyimpangan } \\
\text { sample cov } \\
\text { matrix dan fitted } \\
\text { kecil }<\text { Chisquare } \\
\end{array}$ & 1118,206 & Fit \\
\hline $\begin{array}{c}\text { Root Mean Square Error of } \\
\text { Approx (RMSEA) }\end{array}$ & $\begin{array}{l}\text { Browne dan } \\
\text { Cudeck (1993) } \\
\quad<0,08\end{array}$ & .050 & Fit \\
\hline Model AIC & $\begin{array}{l}\text { Model AIC } \\
\text { > Saturated AIC } \\
<\text { Independence } \\
\text { AIC }\end{array}$ & $\begin{array}{c}\text { 1399,206 > Satura } \\
\text { ted AIC (462) } \\
<\text { Independence } \\
\text { AIC } \\
(1090,897) \\
\end{array}$ & Fit \\
\hline Model CAIC & $\begin{array}{r}\text { Model CAIC }< \\
\quad<\text { Saturated }\end{array}$ & $\begin{array}{c}1614,122<\text { Satura } \\
\text { ted CAIC }\end{array}$ & Fit \\
\hline
\end{tabular}


Published, Volume 20 No. 1, Juli 2020

EKONOMIKAWAN : Jurnal Ilmu Ekonomi dan Studi Pembangunan

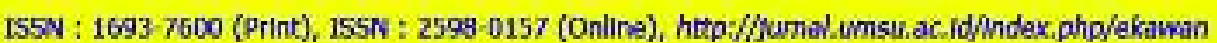

\begin{tabular}{|c|c|c|c|}
\hline & $\begin{array}{c}\text { CAIC } \\
<\text { Independence } \\
\text { CAIC }\end{array}$ & $\begin{array}{c}(1454) \\
\text { <Independence } \\
\text { CAIC } \\
(1317,910)\end{array}$ & Fit \\
\hline Normed Fit Index (NFI) & $>0,90$ & 0.979 & Fit \\
\hline $\begin{array}{c}\text { Parsimoni Normed Fit Index } \\
\text { (PNFI) }\end{array}$ & $0,60-0,90$ & 0.685 & Fit \\
\hline $\begin{array}{c}\text { Parsimoni Comparative Fit } \\
\text { Index (PCFI) }\end{array}$ & $0,60-0,90$ & 0.611 & Fit \\
\hline PRATIO & $0,60-0,90$ & 0.862 & Fit \\
\hline $\begin{array}{c}\text { Comparative Fit Index (CFI) } \\
(\text { Bentler }(2000)\end{array}$ & $>0,90$ & 0.909 & Fit \\
\hline $\begin{array}{c}\text { Incremental Fit Index (IFI) } \\
\text { Byrne (1998) } \\
\text { Relative Fit Index (RFI) }\end{array}$ & $>-1$ & 0.911 & Fit \\
\hline Goodness of Fit Index (GFI) & $>0,90$ & 0.628 & Fit \\
\hline $\begin{array}{c}\text { Adjusted Goodness of Fit } \\
\text { Index (AGFI) }\end{array}$ & $0-1,0$ & 0.996 & Fit \\
\hline $\begin{array}{c}\text { Parsimony Goodness of Fit } \\
\text { Index (PGFI) }\end{array}$ & 0.474 & 0.928 & 0 \\
\hline
\end{tabular}

Sumber : Output, Amos 22.

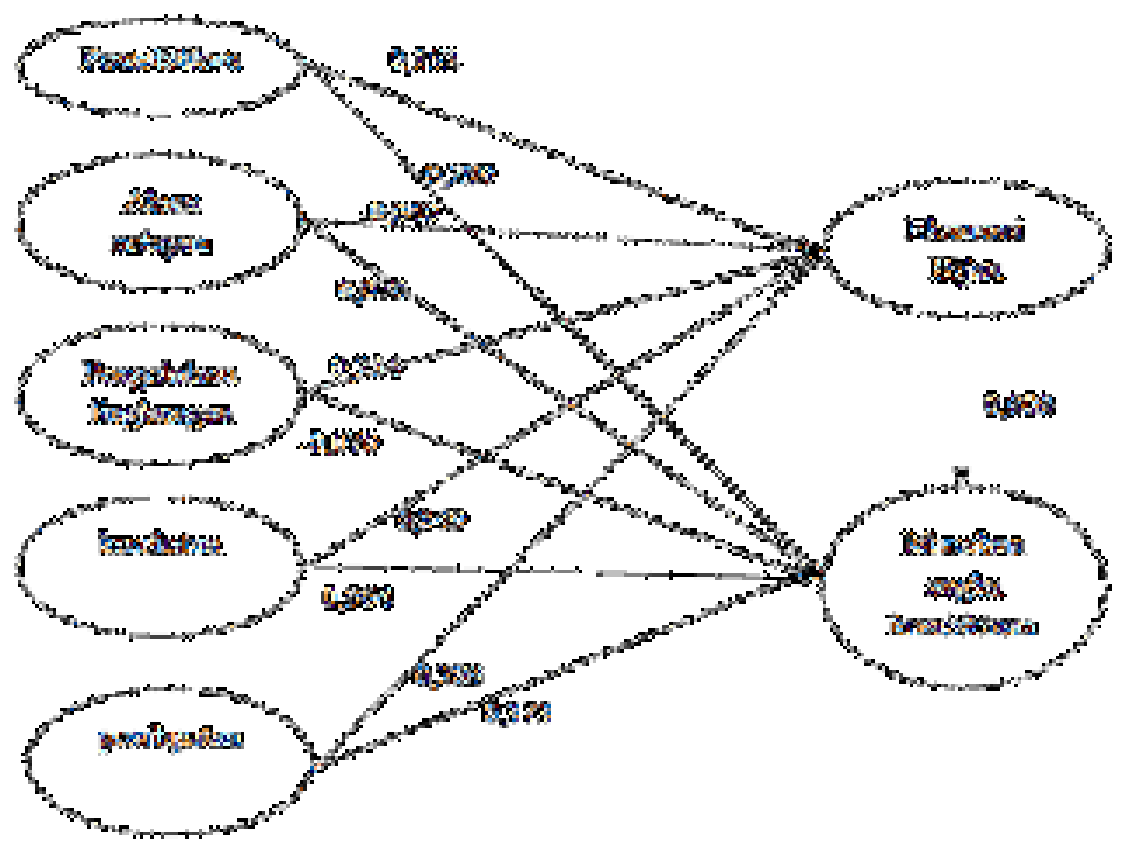

Gambar 5. Total Effect Pendidikan, Akses Nelayan, Pengelolaan Lingkungan, Kesehatan, Dan Pendapatan.

Ilustrasi gambar 5 tersebut bahwa seluruh variabel eksegenous mempengaruhi endegenous secara total. Hasil pengaruh keseluruhan menunjukan bahwa yang mempengaruhi terbesar secara total dalam meredam angka kemiskinan adalah tingkat kesehatan sebesar 0,964 sedangkan yang mempengaruhi terbesar secara total terhadap ekonomi hijau adalah tingkat kesehatan 0,849. 
I55N : 1693 -7600 (print), 155N : 2598 -0157 (Online), http://fumd.umstiac.id/index.php/ekawan

Tabel 2. Hasil estimasi C.R (Critical Ratio) dan P-Value

\begin{tabular}{|c|c|c|c|c|c|c|c|}
\hline & & & Estimate & S.E. & C.R. & $\mathrm{P}$ & Label \\
\hline $\mathrm{EH}$ & $<---$ & PDD & ,462 & ,089 & 5,184 & $* * *$ & par_15 \\
\hline MAK & $<---$ & PDD & ,333 & ,059 & 5,622 & $* * *$ & par_16 \\
\hline $\mathrm{EH}$ & $<---$ & AN &,- 124 & ,084 & $-1,487$ & , 137 & par_17 \\
\hline MAK & $<---$ & AN &, 080 & ,054 & 1,474 &, 140 & par 18 \\
\hline $\mathrm{EH}$ & $<---$ & K & 1,284 & ,057 & 22,577 & $* * *$ & par_19 \\
\hline MAK & $<---$ & K & ,414 & ,027 & 15,456 & $* * *$ & par_20 \\
\hline $\mathrm{EH}$ & $<---$ & PL &,- 135 & ,052 & $-2,605$ & ,009 & par_21 \\
\hline MAK & $<---$ & PL &,- 150 & ,034 & $-4,385$ & $* * *$ & par_22 \\
\hline $\mathrm{EH}$ & $<---$ & PNDPTN & ,444 & ,068 & 6,572 & $* * *$ & par_23 \\
\hline MAK & $<---$ & PNDPTN & ,299 & ,044 & 6,744 & $* * *$ & par_24 \\
\hline pdd 3 & $<---$ & PDD & 1,000 & & & & \\
\hline pdd 2 & $<---$ & PDD & 1,788 & 197 & 9,089 & $* * *$ & par_1 \\
\hline pdd1 & $<---$ & PDD & 1,450 &, 167 & 8,678 & $* * *$ & par_2 \\
\hline an 3 & $<---$ & AN & 1,000 & & & & \\
\hline an2 & $<---$ & AN & 1,081 & ,077 & 13,989 & $* * *$ & par_3 \\
\hline an 1 & $<---$ & AN & 1,110 & ,083 & 13,298 & $* * *$ & par_4 \\
\hline k3 & $<---$ & K & 1,000 & & & & \\
\hline k2 & $<---$ & K & 1,106 & ,052 & 21,423 & $* * *$ & par_5 \\
\hline k1 & $<---$ & K & ,922 & ,048 & 19,349 & $* * *$ & par_6 \\
\hline pl3 & $<---$ & PL & 1,000 & & & & \\
\hline pl2 & $<---$ & PL & ,711 &, 060 & 11,853 & $* * *$ & par_7 \\
\hline pl1 & $<---$ & PL & ,741 & ,070 & 10,623 & $* * *$ & par_8 \\
\hline pndptn3 & $<---$ & PNDPTN & 1,000 & & & & \\
\hline pndptn2 & $<---$ & PNDPTN & ,771 & ,092 & 8,398 & $* * *$ & par_9 \\
\hline pndptn 1 & $<---$ & PNDPTN &, 748 & ,084 & 8,904 & $* * *$ & par_10 \\
\hline eh1 & $<---$ & $\mathrm{EH}$ & 1,000 & & & & \\
\hline eh2 & $<---$ & $\mathrm{EH}$ & ,724 & ,025 & 29,037 & $* * *$ & par_11 \\
\hline eh3 & $<---$ & $\mathrm{EH}$ & ,370 & ,038 & 9,614 & $* * *$ & par_12 \\
\hline mak3 & $<---$ & MAK & 1,000 & & & & \\
\hline mak2 & $<---$ & MAK & ,596 & ,085 & 6,997 & $* * *$ & par_13 \\
\hline mak1 & $<---$ & MAK & ,461 & ,068 & 6,759 & $* * *$ & par_14 \\
\hline
\end{tabular}

Sumber : Lampiran, Amos 22.

\section{Pembahasan}

1. Dari hasil pengujian, terdapat pengaruh signifikan pendidikan terhadap ekonomi hijau. Hasil penelitian menunjukkan tingkat pendidikan masyarakat nelayan sangat buruk, banyak diantara masyarakat nelayan yang buta huruf, bahkan tidak bisa menulis sama sekali. Hal ini diakibatkan oleh kurangnya biaya masyarakat untuk bersekolah, namun tidak hanya biaya, minat masyarakat untuk bersekolah masyarakat Desa Pahlawan pun sangat rendah. Walaupun pemerintah sudah memberikan solusi untuk masyarakat yang tidak mampu dalam menjalankan pendidikan, dengan memberikan pendidikan gratis tetap saja minat mereka sangat rendah. Dan ini bukan berarti sepenuhnya salah pemerintah, karena pemerintah sudah memberikan satu solusi kepada masyarakat. 


\section{EKONOMIKAWAN : Jurnal Ilmu Ekonomi dan Studi Pembangunan}

I55N : $1693-7600$ (print), 155N : 2598-0157 (Online), hutp://fumal_umstiacid//index.php/ekawan

2. Dari hasil pengujian, terdapat pengaruh signifikan pendidikan terhadap meredam angka kemiskinan. Semakin tinggi pendidikan masyarakat Desa Pahlawan pasti mampu mengubah kehidupan masyarakat Desa Pahlawan, dengan berubah nya pola fikir, dan gaya hidup masyarakat. Kenyataannya bahwa mempunyai tingkat pendidikan yang rendah, menyebabkan dilema bagi pemerintah dalam memberikan kontribusi dalam pola pengarahan ataupun pemberian peralatan yang canggih. Keadaan semacam itu berimbas pada kondisi sekitar perumahan karena rendahnya pengetahuan akan pentingnya standar kualitas rumah. Rendahnya pendidikan serta kurangnya informasi sebagai akibat keterisolasian masyarakat nelayan. Tetapi sebagian berfikir edukasi tidak berharga, apalagi bagi masyarakat yang tinggal di pedesaan seperti pada masyarakat Desa Pahlawan yang berada pada wilayah pesisir, mereka menganggap pendidikan tidak berguna karena bagi mereka lebih baik mencari nafkah ketimbang bersekolah. Pertimbangannya jelas lantaran bila mereka bekerja pastinya memperoleh duit, sedangkan sekolah hanya buang-buang uang saja. Ditambah latar belakang yang sangat susah.

3. Dari hasil pengujian, terdapat pengaruh tidak signifikan akses nelayan terhadap ekonomi hijau, bahwa nilai probabilitas sebesar 0,137>0,05 sehingga diketahui akses nelayan tidak signifikan pendekatan ekonomi lingkungan. Tidak Signifikannya akses nelayan terhadap ekonomi hijau pada masyarakat dikarenakan tidak tersedia dengan baik akses nelayan seperti halnya sarana transportasi masyarakat nelayan, masih banyaknya masyarakat nelayan yang masih menggunakan perahu tradisional, hal ini dikarenakan ketidak adanya biaya masyarakat untuk melengkapi perangkat nelayan.

4. Dari hasil pengujian, terdapat pengaruh tidak signifikan akses nelayan terhadap meredam angka kemiskinan, artinya nilai probabilitas sebesar $0,140>0,05$ sehingga diketahui akses nelayan tidak signifikan mempengaruhi meredam angka kemiskinan. Tidak Signifikannya akses nelayan terhadap meredam angka kemiskinan di karenakan kurangnya modal masyarakat di desa tersebut dan hanya mengandalkan bantuan dari pemerintah daerah setempat, juga diakibatkan oleh hasil yang didapat tidak sesuai dengan kategori hasil yang ditentukan oleh pemilik kapal. Karena masih banyaknya masyarakat nelayan yang masih menggunakan sistem bagi hasil, jika hasil tangkap yang didapat melimpah dan dijual kepasaran, setelahnya mereka akan membagi hasil pendapatan, terkadang hasil yang mereka dapatkan hanya bisa mencukupi kebutuhan mereka untuk hari ini saja, namun jika hasil tangkap sedikit, maka yang akan mereka terima hanya berupa ikan yang hanya cukup untuk makan 1 kali saja.

5. Dari hasil pengujian, terdapat pengaruh signifikan kesehatan terhadap ekonomi hijau dikarenakan ekonomi hijau dan kesehatan saling keterkaitan, sehingga perbaikan pada kondisi kesehatan masyarakat akan mempengaruhi produktifitas pekerjaan, keterkaitan kesehatan terhadap pendekatan ekonomi hijau tidak dapat dipisahkan. Konsekuensi yang tampak dari pencemaran lingkungan bukan cuma dapat menghancurkan biota dan lingkungan laut, namun bisa membahayakan kesehatan individu atau bahkan menyebabkan kematian, mengurangi atau merusak nilai estetika lingkungan pesisir dan lautan menimbulkan kerugian secara sosial ekonomi.

6. Dari hasil pengujian, terdapat pengaruh signifikan kesehatan terhadap meredam angka kemiskinan. Dalam mencapai kehidupan yang lebih baik kesehatan menjadi faktor yang penting agar mereka bisa terus menjalankan kegiatan mereka sebagai nelayan serta bisa mencukupi hajat hidup sehari-hari, tentunya saja tidak sepenuhnya langsung mengurangi angka kemiskinan paling tidak mereka mampu memenuhi kebutuhan hidup harian mereka. 


\section{EKONOMIKAWAN : Jurnal Ilmu Ekonomi dan Studi Pembangunan}

I55N : $1693-7600$ (print), 155N : 2598-0157 (Online), hutp://fumal_umstiacid//index.php/ekawan

7. Dari hasil pengujian, terdapat pengaruh tidak signifikan pengelolaan lingkungan terhadap ekonomi hijau, dimana nilai probabilitas sebesar 0,009>0,05 sehingga diketahui pengelolaan lingkungan tidak signifikan mempengaruhi pendekatan ekonomi hijau. Tidak signifikannya lingkungan terhadap ekonomi hijau dikarenakan tidak terkelolanya lingkungan dengan baik, hasil penelitian menunjukkan lingkungan di Desa Pahlawan sangat buruk, dengan kondisi sampah yang berserakan dimanamana, terlebih lagi sampah rumah tangga masyarakat dibuang langsung ke laut, yang mana air laut tersebut berhubungan langsung dengan bibir pantai yang ada di desa itu. Laut yang sudah tercemar oleh sampah maka akan berdampak buruk pada sumber dayanya, seperti ikan yang tidak sehat, dan perlahan mati karena air yang kotor mengakibatkan timbulnya berbagai penyakit lainnya.

8. Dari hasil pengujian, terdapat pengaruh signifikan pengelolaan lingkungan terhadap meredam angka kemiskinan, lingkungan yang sehat akan berdampak pada sumber daya yang sehat. Sebaliknya apabila rendahnya pengelolaan lingkungan yang berakibat berkurangnya ikan-ikan yang ada di sungai dan di laut, juga mengakibatkan semakin menurunnya hasil tangkap masyarakat terhadap sumber daya tersebut, sehingga kecil kemungkinan bagi masyarakat untuk mensejahterakan kehidupan mereka, harusnya masyarakat tahu apa dampak dari perbuatan mereka yang membuang sampah di sembarang tempat, dan kurangnya terjaga lingkungan mereka untuk jangka waktu panjang ke depan. Pada kenyataannya saat ini himpitan permasalahan ekonomi dikalangan masyarakat pesisir memaksa mereka untuk melakukan segala cara untuk bisa bertahan hidup dan menjaga kelangsungan hidup keluarganya. Kehidupan nelayan terutama pada lapisan buruh dalam kegiatan penangkapan ikan tergantung pada juragan ikan atau pemilik kapal dan modal. Hal itu diakibatkan oleh kekurangan modal atau finansial yang memadai.

9. Dari hasil pengujian, terdapat pengaruh signifikan pendapatan terhadap pendekatan ekonomi hijau. Hasil penelitian membuktikan bahwa pendapatan dapat berpengaruh terhadap ekonomi hijau, karena jika dengan adanya kualitas masyarakat yang baik, maka masyarakat mampu mendekatkan diri dengan lingkungan serta menjadikan lingkungan sebagai menambah penghasilan ekonomi masyarakat. Sebagai contoh seperti masyarakat nelayan Desa Pahlawan, jika mereka memiliki kualitas masyarakat yang baik tentu saja masyarakat bisa berkreativitas dengan cara penggunaan barang yang tidak terpakai menjadi barang terbarukan dan dapat diperjualbelikan sebagai tambahan pendapatan keluarga.

10. Dari hasil pengujian, terdapat pengaruh signifikan pendapatan terhadap meredam angka kemiskinan. Besarnya pendapatan yang diterima oleh masyarakat nelayan tergantung dari hasil tangkap sekali melaut untuk dijadikan konsumsi keluarga. Kemiskinan yang dirasakan dikarenakan keterbatasan sumber daya modal, keahlian sehingga mendorong terjadinya eksploitasi sumber daya laut secara berlebihan tanpa adanya pengembangbiakan atau membudidayakan kembali sumber daya ikan tersebut.

\section{SIMPULAN}

Akses nelayan terdapat pengaruh yang tidak signifikan terhadap pendekatan ekonomi hijau dan meredam angka kemiskinan, ini sejalan dengan hasil penelitian oleh Soeparmoko (2014) menunjukan bahwa signifikannya pendidikan terhadap meredam angka kemiskinan karna pendidikan itu penting untuk kesehjahteraan masyarakat. Serta Luh Putu Putri Awandari (2012) menunjukan bahwa akses nelayan, tidak signifikannya akses nelayan terhadap pengentasan kemiskinan masyarakat di karenakan kurangnya modal masyarakat 


\section{EKONOMIKAWAN : Jurnal Ilmu Ekonomi dan Studi Pembangunan}

I55N : $1693-7600$ (print), 155N : 2598-0157 (Online), hutp://fumal_umstiacid//index.php/ekawan

di desa tersebut dan hanya mengandalkan buatan dari pemerintah daerah setempat. Sama halnya dengan pengelolaan lingkungan terdapat pengaruh yang tidak signifikan terhadap ekonomi hijau. Hal ini didukung oleh Soemarwoto \& Batamen, (2005) bahwa ketersediaan sumber daya alam akan terjaga apabila lingkungan terjaga dengan baik, akan terjadi kerugian (berkurang kesejahteraan masyarakat) yang tidak dikompensasi akibat limbah ke lingkungan.

\section{DAFTAR PUSTAKA}

Abdul Halim. (2016). buku 1, Keterkaitan Pengetahuan Terhadap Pengelolaan Sumber Daya Alam Dan Lingkungan. Jakarta : Salemba Empat.

Albornoz, M. A., Becker, M., Cahyat, A., Cronkleton, P., Jong, W.d., Evans, K., Wollenberg, E. (2007). Menuju Kesejahteraan dalam Masyarakat Hutan: Buku Panduan untuk Pemerintah Daerah. Bogor : Cifor.

Atriana Nara. (2014). Pengaruh Tingkat Pendapatan Terhadap Kesejahteraan Masyarakat. Yogyakarta: Penerbit Andi.

Bush. (2008). Pengelolaan Lingkungan dan Pengelolaan Kawasan Pesisir dan Laut.

Cato, M.S., Green Economics: An Introduction to Theory, Policy and Practice, earthscan, London, (2009), dalam Sudarsono Soedomo, Ekonomi Hijau: Pendekatan Sosial, Kultural dan Teknologi, makalah pada Diskusi "Konsep Ekonomi Hijau/Pembangunan Ekonomi yang Berkelanjutan untuk Indonesia, Jakarta 14 Juli 2010: hlm. 6-7.

Case, K. E, \& Fair, R. C. (2010). Prinsip-prinsip Ekonomi. Ed. Ke 8, J1. I. Jakarta : Penerbit Erlangga.

David Ricardo. (2003). Manusia Akan Selalu Menggunakan Sumber Daya Alam Yang Paling Tinggi Kualitasnya Kemudian Baru Beralih Kekualitas Yang Rendah.

Emil Salim. (2015). Pengawasan Berwawasan Lingkungan Hidup. Jakarta : UI-Press.

Global Watre Partnership. (2001). Pengelolaan Lingkungan

Hendrik L. Blum. (2008). Pencegahan Penyakit Yang Disebabkan Oleh Lingkungan.

Faried, Annisa Ilmi. (2018). Analisis Dampak Pencemaran Lingkungan Terhadap Faktor Sosial Ekonomi Pada Wilayah Pesisir di Desa Pahlawan Kecamatan Tanjung Tiram Kabupaten Batu Bara.

Gonner, C., Cahyat, A., Haug, M., \& Godwin Limberg. (2007). Menuju Kesejahteraan: Pemantauan Kemiskinan di Kutai Barat, Indonesia. Bogor : Cifor.

Grigg. (2008). Panduan Rakordal Bidan Rencana Program Kegiatan Lingkungan Hidup. Semarang: Bapedalda Dati I Jateng 1999.

Mankiw. 2007. Pendapatan Masyarakat Nelayan. http://googlebooks.

Paune. 2012. Prosedur Penelitian Suatu Pendekatan Praktek Kesehatan. Jakarta : Rineka Cipta.

Schlager Dan Ostrom. 2010. Analisis Vegetasi Dan Tingkat Kesejahteraan Masyarakat Pengelola Agroforestri Di Desa Sumber Agung Kecamatan Kemiling Kota Bandar Lampung.

Wijaya, toni.( 2009). Analisis Structural Equation Model Menggunakan Amos. Yogyakarta : Universitas Atma Jaya Yogyakarta.

Yamin, Sofyan. (2009). Structural Equation Modeling: Belajar Lebih Mudah Teknik Analisis Data Kuesioner dengan Lister-PLS. Jakarta : Salemba infotek. 